\title{
E-loyalty:A Study on E-loyalty of Conventional Bank Customers in Banda Aceh City, Indonesia
}

\author{
Hafasnuddin Fakhrurrazi Sofyan Idris \\ Lecturer of Economics and Business Faculty - Syiah Kuala University, Banda Aceh, Indonesia
}

\begin{abstract}
The purpose of this research is to analyze e-loyalty of conventional bank customers through a qualitative approach. The research was conducted in the city of Banda Aceh, Aceh Province (Indonesia) by determining a total sample size of 200 samples which were selected through purposive sampling method. A total of 385 respondents were given a set of questionnaires but after a period of 3 months only 156 respondents sent back the questionnaire (response rate was $40.52 \%$ ). The results of the study found that the average score of e-customer loyalty to conventional banks that have internet banking facilities is high, they feel that internet banking can really fulfill their personal needs, easily and efficiently make transactions anywhere and anytime, and through the use of internet banking they feel more prestigious.
\end{abstract}

Keywords: e-loyalty, internet banking, conventional bank, personal need, efficiency, prestige

DOI: $10.7176 / \mathrm{EJBM} / 12-36-07$

Publication date: December $31^{\text {st }} 2020$

\section{Introduction}

Internet banking provides various facilities to bank customers so that the customers can complete various transactions electronically wherever they are and whenever they want with low fees and a much shorter time than before the existence of the bank's internet facility (Yoon and Steege, 2013; Narayanasamy et al., 2011; Siyal at al., 2019; Raza et al., 2020). Through these various benefits and conveniences, internet banking plays an imperative role in decreasing fixed and variable costs for bank customers (Chen et al., 2012), while for banking institutions, by providing it banks can build and foster better relationships with their customers (Rod et al., 2009; Rod and Ashill, 2010; Siyal at al., 2019).

On the one hand, despite the lack of understanding of bank customers on how to use e-banking (Karjaluoto et al, 2002), but on the other hand, the serious readiness of them to adapt to using internet banking is a foremost aspect (Al-Alak, 2014; Harrison et al., 2014; Al-Ajam and Md Nor, 2015; Chaouali et al., 2016) which causes customers to strive with seriously changing their traditions to try to comprehend the way of using the internet banking. However, there are also numerous consumers who are hesitant to use the internet banking (Chaouali et al., 2016; Tarhini et al., 2016).

The way customers view internet-based banking services is quite different from the way they view banks that have not used it. To find out these different views, an analysis is needed not only regarding the need for an internetbased banking services (George and Kumar, 2014; Kaura et al., 2015; Ranaweera \& Sigala, 2015; Siyal et al., 2019) but also banks need to identify how customers evaluate the main characteristics or dimensions of internetbased banking services (Amin, 2016).

E-loyalty of customers to banks that have internet banking facilities can be caused by various characteristics of the internet banking website. Preceding researches have tried to classify the aspects that cause customer allegiance in the banking industry due to the characteristics of the website (Bansal et al., 2004; Anderson and Swaminathan, 2011; Liébana-Cabanillas et al., 2013), and e-banking attribute quality (Cristobal et al., 2007; Moon et al., 2011; Adapa and Roy 2017). According to Chen et al., 2012; Chen, 2013; Dahlstrom et al., 2014; Marafon et al., 2018), for example, e-loyalty can be achieved when customers feel there is no risk in using internet banking for transactions carried out, while Black et al., (2014) argue that e-loyalty will be attained when the internet service facility can further strengthen good relationship between customers and bank institutions as service providers, relative advantage (Adapa and Roy, 2017), usefulness and perceived ease of use (Alalwan et al.,2016; Chaouali et al., 2016; Koo et al., 2015; Mital et al., 2018; Rawashdeh, 2015).

Besides the characteristics of the internet banking website, traditions and personal interests are also the two foremost aspects that influence customers to use and then be loyal to the banks which provide internet banking (McNeish, 2015), then added with social links, interpersonal affiliations, societal conditions in civilization nowadays and need for a sense of safekeeping are also factors that increase public awareness of the need for internet banking facilities (Hasim and Salman, 2010). However, the results of preliminary study in early of 2020 on conventional bank customers in Banda Aceh (Indonesia) found that the main characteristics a website that can lead to customer e-loyalty to the bank include ease of access and use, can be used anytime and anywhere, guaranteed safety and fulfillment of customer's personal needs. The characteristics of the internet banking desired by bank customers that cause their e-loyalty to the banks constitute a gap in this study. Therefore, this study tries to analyze this research gap qualitatively. It should also be noted that the systematic writing of the results of this 
qualitative research begins with background phenomena, review of literature studies, research methods, and discussion of research results, and then ends with some conclusions and suggestions.

\section{Literature review}

\subsection{Internet banking}

Internet banking or e-banking is an online service operated by banks using internet technology that aims to make it easier for customers to carry out all banking transactions such as money transfers, balance checks, access to banking products such as opening savings, deposits, paying credit card bills, electricity, water and others (Nugroho, 2019).

To be able to access and use internet banking services, customers need to have a smart phone or laptop/tablet and then have sufficient internet data for a fast internet connection. The bank does not charge any fees for the usage of e-banking facilities. The first thing a customer must do to be able to use e-banking services is to activate internet banking by registering directly at the nearest bank office or customers can also register through an ATM machine.

Generally, at the initial stage, customers can usually use the internet banking facility only to check transaction such as checking balance, while for financial transactions the internet banking facility cannot be used yet. If the customer wants to expand the quality of internet banking facility so that he can use to financial transactions via internet banking, the customer through the bank's customer service can verify administrative, personal identity data and other related data in order to obtain tokens. For convenience, some banks do not use tokens but provide a one-time password (OTP) via SMS. When a customer uses e-banking for transactions using OTP which sent via SMS to him, the customer must enter the OTP code when making a transaction.

For token users, the transaction process is also very easy. Visit the bank's website, then select internet banking service, enter your user ID and password. Select the desired menu, and lastly, just follow the instructions as listed on the menu, including activating the token for the first time. When the transaction is complete, the customer will receive proof of the transaction sent to the email that the customer has registered.

For convenience, some banks do not use tokens but provide a one time password (OTP) via SMS. When a customer uses internet banking for transactions using OTP which sent via SMS to him, the customer must enter the OTP code when making a transaction. For token users, the transaction process is also very easy. Visit the bank's website, then select internet banking service, enter your user ID and password. Select the desired menu, and lastly, just follow the instructions as listed on the menu, including activating the token for the first time. When the transaction is complete, the customer will receive proof of the transaction sent to the email that the customer has registered.

\subsection{Advantages and disadvantages of Internet Banking.}

Previously, transactions correlated to depositing and withdrawing money were carried out in the customary manner, specifically through a bank teller or ATM or by means of a CDM machine (cash deposit appliance for cash deposits deprived of going through a teller). However, after the existence of internet banking facility, the facility really provides benefits for bank customers to transact very quickly anywhere and anytime (Nugroho, 2019). The advantages of Internet Banking, among others: (a) Practical and free. The Internet banking facility truly realizes the convenience of bank customers to make a series of transactions very quickly anywhere and anytime without being charged a fee by the bank. (b) At anytime and anywhere customers can create, carry out, and schedule various kinds of bank transactions quickly and easily, such as transferring money between banks, checking balances and account mutations, paying credit card bills, paying once-a-month bills (such as energy bills, telephone bills, water bills, education fees, subscription TV), paying for dealings in e-commerce (shopping virtual, paying for airplane tickets, paying for hotels, etc). (c) Bank customers can open savings account, savings for education, buying insurance, buying mutual funds and etc. All of these accounts can be opened quickly and safely. (d) Check the exchange rate of the rupiah against the currencies of other nation states, such as the American dollar, Singapore dollar and others. (e) customers can easily update innumerable packages and the newest product launched by the banks. (f) For banks, it can save operational costs.

On the other hand, Internet Banking also has various shortcomings, such as: (a) Prone to theft and data interception. Customers and banks also need to be aware of cyber-crimes by hackers which will result in the formation of a negative image of bank. Hacker crimes, such as theft of customer data in e-banking can occur if customers are careless. To prevent these hackers, customers must comply with all proper procedures for using ebanking so that they can be protected from hackers. Meanwhile, the bank must regularly supervise and keep ebanking technology in a well-maintained condition. (b) Vulnerable to online delinquency with a number of fraud means such as scanning techniques, deception, persuasion by offering fake gifts etc. Customers do not be straightforwardly interested by unreasonable offers or tantalizing advertisements. (c) Prone to malware/virus attacks. Bank customers should always be vigilant and prevent virus attacks that can occur at anytime and anywhere. For prevention, customers should use a data package or a secure internet connection so that they are not 
exposed to this virus attack. Bank customers should not use free VPN connections and public Wi-Fi because these connections contain lots of viruses. Customers should ensure that their smartphones/laptops have installed antivirus and anti-malware software to avoid cracking. (d) In remote areas the internet connection signal is low so that the e-banking cannot be accessed and e-banking cannot be used automatically.

\section{3. e-Customer loyalty}

Especially in banking sector industry, Anderson and Srinivasan (2003) define e-customer loyalty is a propensity of customers to carry on using particular website, repeatedly use it, show an extraordinary attachment to the website and strongly believe that it is safe and comfortable. A slightly similar opinion is also given by Caruana (2002), Baumann et al., (2012), Rawashdeh (2015), and Siyal et al (2019) who suggest that customers often form patterns of attitudes towards repurchasing behavior based on service experiences obtained in the past. The two definitions emphasize two important aspects in defining e-loyalty, namely the frequency of repeating the use of internet banking and a positive attitude towards it. Therefore, in general it can be said that e-customer loyalty can be analyzed by using two perspectives, namely behavioral perspective and attitude perspective.

By applying the behavioral perspective, e-loyalty of customers is indicated through the behavior of customers' desire to continue using e-banking in the forthcoming (Kandampully et al., 2015; Melnyk and Bijmolt, 2015; Siyal et al.,2019), and bank customers will also increase the use of internet banking in the upcoming (Liébana et al.,2017). Meanwhile, by using the attitude perspective, the e-loyalty of customers is appointed with a manifestation of a positive attitude towards a certain e-banking and then they recommend it to other parties to use that e-banking (Kaur et al., 2012; Amin, 2016).

There are several characteristics of internet banking that can provide benefits to bank customers so that they will be loyal to banks which have the internet banking facilities. Gera (2011), for example, really underlines that a positive interaction experience with a website is the most important factor that can influence customers' choice to return to the site and provide encouraging endorsements to others. According to Jeong and Lee (2010), Kaur et al., (2012), Rawashdeh (2015), through internet banking facilities which can truly fulfill the needs and desires of customers, banking institutions will really get customers who have high loyalty to the banks. Then, the highly loyal customers will not only frequently visit and use the same website but will also actually recommend others to use it. (Kaur et al., 2012; Amin, 2016). Next, bank customers who have high loyalty certainly have a great commitment to remain via internet banking facilities steadily in the coming years (Fraering and Minor, 2013; Kandampully et al., 2015; Melnyk and Bijmolt, 2015), then they will also prevent expressing negative Word of Mouth (WOM) to anyone (Kaur et al., 2012; Amin, 2016). Furthermore, the results of studies conducted by Rawashdeh (2015), Mital et al (2018) and Siyal et al (2019) found that the important factor of e-loyalty occurs when e-banking has characteristics of PU (perceived usefulness) and PEOU (perceived ease of use).

\section{Research Method}

\subsection{Sample and Data Analysis}

The research was conducted in the middle of 2020 in Banda Aceh city, Aceh Province (Indonesia). Conventional bank customers who use internet banking facilities are the population of this study. The number of respondents was determined as many as 200 samples selected based on the purposive sampling method, namely conventional bank customers who have been customers of the conventional banks for at least the last one year, have owned smartphones and reside in areas that can always access the internet network smoothly. Until mid-2020, there are seven conventional banks operating in Banda Aceh. Each bank was determined as many as 55 respondents so that total numbers of all samples were 385 respondents.

Data was collected by giving a set of questionnaires to 385 respondents found in the conventional bank. After waiting for three months, out of 385 respondents who were given a set of questionnaires only 174 were sent back, 18 questionnaires were not filled in completely so they could not be processed further. Therefore, only 156 respondents' answers could be processed further (response rate was $40.52 \%$ ). All data that has been collected is processed through a qualitative approach and then analyzed based on a marketing approach, especially consumer behavior with regard to e-loyalty.

\subsection{Measurement}

Each respondent was asked to circle one of five choices of statements about the extent to which he/she agreed with each of these statements using a Likert scale range of 1 to 5 . A score of 1 means strongly disagree while a score of 5 means strongly agree. This e-loyalty research covers the extent to which conventional bank e-banking service can fulfill the personal needs of their customers, safely and efficiently using it. The e-loyalty analysis is carried out through two approaches, namely a behavioral approach and an attitude approach so that it will be known that there are desires of customers to remain as customers of conventional banks that have internet banking facilities in the future, and they will also recommend the banks to other potential customers. 


\section{Results and Discussions}

\subsection{Benefits of internet banking}

Internet banking facility does provide various benefits to bank customers such as financial benefits, time saving benefits, prestige benefits, and security benefits. In other words, internet banking can fulfill various personal needs of bank customers. Average score of the customers' assessment of the benefits they get by using internet banking for various transactions is 4.62 on a Likert scale. They get financial benefits and time benefits because when they carry out transactions they no longer need to spend money and to spend time going to the bank or ATM which sometimes requires queues. The findings are in agreement with the outcome of a study steered by Adapa and Roy (2017), Sánchez-Torres et al., (2018), Yaseen and El Qirem (2018). Besides that, they only need very little time to carry out each transaction. Next, the transactions can be done anywhere and anytime as well as the ease of using the internet banking facility. Furthermore, bank customers also get prestige benefits because they view that by using internet banking they feel more prestigious for the reason that the use of it is now a lifestyle model in digital era and a symbol of middle and upper social class status. The following table shows the average score of customer needs and desires that are fulfilled by using internet banking.

Table 1. The average score of the fulfillment of customer needs using internet banking.

\begin{tabular}{|c|l|c|}
\hline N0 & \multicolumn{1}{|c|}{ Personal Needs } & $\begin{array}{c}\text { Average } \\
\text { score }\end{array}$ \\
\hline 1 & Doing transactions via internet banking can save my financial expenses. & 4.61 \\
\hline 2 & By using internet banking to make transactions, I get a saving of my time & 4.64 \\
\hline 3 & $\begin{array}{l}\text { My personal needs and desires have been fulfilled through the use of internet banking } \\
\text { facilities. }\end{array}$ & 4.58 \\
\hline 4 & I really feel safe transacting using online bank websites & 4.63 \\
\hline 5 & Today, internet banking is a reflection of social status and prestige value in society & 4.63 \\
\hline & Average score & 4.62 \\
\hline
\end{tabular}

Source: Field study, 2020

\subsection{Internet Banking Efficiency}

Average efficiency score received by customers by using the e-banking facility is 4.58 on a Likert scale. Through the use of internet banking, customers can acquire various efficiencies such as financial efficiency and time efficiency. By using internet banking, the bank's customers actually gain a dramatic reduction in spending their money and time on transactions because they no longer need to go to bank tellers or ATMs to complete transactions. In terms of time and place when using it, the internet banking facility is also very flexible since it can be used anytime and anywhere. This finding is in line with several studies conducted by Cheng and Yeung (2006), Amin, (2016), Salimon et al (2017), Anouze and Alamro (2020)

Besides that, internet banking also has guidelines that are easy to understand and to follow when using it so that bank customers really enjoy it and are interested in continuing to use it. Therefore, on the basis of these various efficiencies, bank customers view that the efficient use of internet banking is not only obtained in the form of financial and time efficiency, but also efficiency in the ease and flexibility of time and place when using it. The following table informs average efficiency score received by conventional bank customers.

Table 2 . The average efficiency score received by customers through the use of internet banking facility.

\begin{tabular}{|c|l|c|}
\hline No & \multicolumn{1}{|c|}{ Indicators of efficiency } & $\begin{array}{l}\text { Mean } \\
\text { score }\end{array}$ \\
\hline 1 & Bank website provides me a clear and easy guide & 4.53 \\
\hline 2 & I really feel that it is easy to find what I need on bank website. & 4.51 \\
\hline 3 & Anywhere and anytime the bank website is really easy to access. & 4.5 \\
\hline 4 & I carry out various transactions through the online bank website in quite a short time. & 4.58 \\
\hline & Average score & 4.53 \\
\hline
\end{tabular}

Source: Field study, 2020

\subsection{E-loyalty of bank customers}

The average score of e-customer loyalty to banks that have internet banking facilities is high, namely 4.58 on a Likert scale. The finding proves that customers will truly be loyal to banks that have internet banking service facilities. The finding is consistent with the results of a study conducted by Marafon et al. (2018), Anouze and Alamro (2020), Raza et al., (2020). It means that when the e-loyalty of customers is at a high level, in the future they will have a strong commitment to remain bank customers which have internet banking facilities, they desire to increase the frequency of transactions through it and their unwillingness to become bank customers that do not provide e-services. The following table shows the average score of e-customer loyalty to banks that have ebanking services based on a behavioral approach. 
Table 3. The average score of e-customer loyalty based on behavioral approach.

\begin{tabular}{|c|l|c|}
\hline No & \multicolumn{1}{|c|}{ Indicators of e-loyalty } & $\begin{array}{l}\text { Mean } \\
\text { score }\end{array}$ \\
\hline 1 & In the future I intend to remain a bank customer that has internet banking facilities & 4.57 \\
\hline 2 & $\begin{array}{l}\text { I intend to increase the frequency of transactions using internet banking facilities in the } \\
\text { coming years }\end{array}$ & 4.60 \\
\hline 3 & $\begin{array}{l}\text { I do not intend to become a bank customer that does not have internet banking service } \\
\text { facilities. }\end{array}$ & 4.62 \\
\hline & Average score & 4.58 \\
\hline
\end{tabular}

Source: Field study, 2020

Based on attitude approach, the average score of e-loyalty of customers to banks that have internet banking service facilities is also high, namely 4.46 on a Likert scale. The finding is an indication that bank customers will be loyal to banks that have e-banking facilities. It means that they will recommend the bank to their family, their relatives, their friends and also to anyone they meet who is looking for information about the bank. Their recommendations are free promotion in the form of words of mouth which are conveyed by them to other potential customers regarding the various positive sides of the banks that have e-banking. According to Zeithaml et al (2003), these recommendations are more effective than advertisements or other promotions. The following table provides more information about the average score of e-customer loyalty based on an attitudinal approach.

Table 4. The average score of e-customer loyalty based on an attitudinal approach

\begin{tabular}{|c|l|c|}
\hline No & \multicolumn{1}{|c|}{ Indicators of e-loyalty } & $\begin{array}{l}\text { Mean } \\
\text { score }\end{array}$ \\
\hline 1 & I will recommend banks which have an e-banking facility to my relatives & 4.64 \\
\hline 2 & I would like to recommend banks that have an e-banking to my families & 4.58 \\
\hline 3 & I would absolutely recommend bank that have internet banking to my friends. & 4.62 \\
\hline 4 & $\begin{array}{l}\text { I will advocate and recommend banks that have internet banking facilities to people who are } \\
\text { looking for information about bank services }\end{array}$ & 4.56 \\
\hline & Average score & 4.60 \\
\hline
\end{tabular}

Source: Field study, 2020

\section{Conclusion and Recommendation.}

On the basis of the findings and analysis mentioned above, several conclusions can be drawn and then suggest some recommendations as follows:

1. Average score of internet banking that can fulfill customers' personal needs is high. It means that internet banking can truly fulfill various personal needs of customers such as financial savings benefits, time saving benefits, prestige benefits and security benefits, while for banking itself internet banking can reduce bank operational costs. Therefore, banking institutions should encourage their customers to use more e-banking for transactions by giving awards to customers who always use e-banking in completing transactions.

2. By using internet banking for transactions, conventional bank customers gain various efficiencies such as financial efficiency, time efficiency needed for transactions, efficiency in using e-banking because there are guidelines that are very easy to understand, and flexibility efficiency because transactions can be carried out anywhere and anytime. Therefore, banking institutions should always revise the appearance of the internet banking menu in a more attractive appearance, have guidelines that are easy to understand and can be used as easily as possible.

3. The average score of e-customer loyalty to conventional banks that have e-banking is high. It means that in the future they will continue to use banks which have e-banking, recommending the bank to their families, relatives, and friends and also anyone they meet who are looking for information about the bank. Their recommendation is a free promotion in the form of positive word of mouth (WOM) which they convey to prospective customers regarding the various positive sides of banks that have e-banking. So, Banks need to maintain these WOMs because these positive WOMs are sometimes more effective than advertisements or other promotions.

\section{REFERENCE}

Adapa, S. and Roy, S. (2017), “Consumers' post-adoption behavior towards internet banking: empirical evidence from Australia”, Behavior \& Information Technology, Vol. 36 No. 9, pp. 970-983.

Al-Ajam, A.S. and Md Nor, K. (2015), "Challenges of adoption of internet banking service in Yemen", International Journal of Bank Marketing, Vol. 33 No. 2, pp. 178-194.

Al-alak, B.A. (2014), "Impact of marketing activities on relationship quality in the Malaysian banking sector", Journal of Retailing and Consumer Services, Vol. 21 No. 3, pp. 347-356.

Alalwan, A., Dwivedi, Y., Rana, N. and Simintiras, A. (2016), “Jordanian consumers' adoption of telebanking: 
Influence of perceived usefulness, trust and self-efficacy”, International Journal of Bank Marketing, Vol. 34 No. 5, pp. 690-709.

Amin, Muslim, (2016),"Internet banking service quality and its implication on e-customer satisfaction and ecustomer loyalty", International Journal of Bank Marketing, Vol. 34 Issue 3 pp. 280 - 306.

Anderson, R.E. and Swaminathan, S. (2011), "Customer satisfaction and loyalty in e-markets: a PLS path modeling approach", The Journal of Marketing Theory and Practice, Vol. 19 No. 2, pp. 221-234.

Anouze , A.L.M. and Ahmed S. Alamro., (2020), "Factors affecting intention to use e-banking in Jordan", International Journal of Bank Marketing, Vol.38 No. 1. pp. 86-112

Bansal, H.S., McDougall, G.H., Dikolli, S.S. and Sedatole, K.L. (2004), "Relating e-satisfaction to behavioral outcomes: an empirical study", Journal of Services Marketing, Vol. 18 No. 4, pp. 290-302.

Baumann, C., Hamin, H. and Tung, R.L. (2012), "Share of wallet in retail banking”, International Journal of Bank Marketing, Vol. 30 No. 2, pp. 88-101.

Black, H.G., Childers, C.Y. and Vincent, L.Y. (2014), "Service characteristics' impact on key service quality relationships: a meta-analysis”, Journal of Services Marketing, Vol. 28 No. 4, pp. 276-291.

Caruana, A. (2002), "Service loyalty: the effects of service quality and the mediating role of customer satisfaction", European Journal of Marketing, Vol. 36 No. 7/8, pp. 811-828.

Chaouali, W., Ben Yahia, I. and Souiden, N. (2016), "The interplay of counter-conformity motivation, social influence, and trust in customers' intention to adopt Internet banking services: The case of an emerging country", Journal of Retailing and Consumer Services, Vol. 28 No. 1, pp. 209-218.

Chen, C. (2013), "Perceived risk, usage frequency of mobile banking services", Managing Service Quality: $A n$ International Journal, Vol. 23 No. 5, pp. 410-436.

Chen, R.-F., Hsiao, J.-L. and Hwang, H.-G. (2012), "Measuring customer satisfaction of Internet banking in Taiwan: scale development and validation", Total Quality Management \& Business Excellence, Vol. 23 Nos 7/8, pp. 749-767.

Cheng, E., Lam, Y. and Yeung, C. (2006), "Intention to use of internet banking: an empirical study inHong Kong ”, Decision Support Systems, Vol. 42 No. 3, pp. 1558-1572.

Cristobal, E., Flavián, C. and Guinalíu, M. (2007), "Perceived e-service quality (PeSQ): measurement validation and effects on consumer satisfaction and web site loyalty", Managing Service Quality, Vol. 17 No. 3, pp. 317-340.

Dahlstrom, R., Nygaard, A., Kimasheva, M. and Ulvnes, A.M. (2014), "How to recover trust in the banking industry? A game theory approach to empirical analyses of bank and corporate customer relationships", International Journal of Bank Marketing, Vol. 32 No. 4, pp. 268-278.

Fraering, M. and Minor, M.S. (2013), "Beyond loyalty: customer satisfaction, loyalty, and fortitude", Journal of Services Marketing, Vol. 27 No. 4, pp. 334-344.

George, A. and Kumar, G.G. (2014), "Impact of service quality dimensions in internet banking on customer satisfaction”, Decision, Vol. 41 No. 1, pp. 73-85.

Gera, R. (2011), "Modelling e-service quality and its consequences in India: an SEM approach", Journal of Research in Interactive Marketing, Vol. 5 Nos 2/3, pp. 203-225.

Harrison, T.S., Onyia, O.P. and Tagg, S.K. (2014), "Towards a universal model of internet banking adoption: initial conceptualization”, International Journal of Bank Marketing, Vol. 32 No. 7, pp. 647-687.

Hasim, M.S. and Salman, A. (2010), "Factors affecting sustainability of internet usage among youth", The Electronic Library, Vol. 28 No. 2, pp. 300-313.

Jeong, Y. and Lee, Y. (2010), "A study on the customer satisfaction and customer loyalty of furniture purchaser in on-line shop", Asian Journal on Quality, Vol. 11 No. 2, pp. 146-156.

Kandampully, J., Zhang, T. and Bilgihan, A. (2015), "Customer loyalty: a review and future directions with a special focus on the hospitality industry", International Journal of Contemporary Hospitality Management, Vol. 27 No. 3, pp. 379-414.

Karjaluoto, H., Mattila, M. and Pento, T. (2002), "Factors underlying attitude formation towards online banking in Finland", International Journal of Bank Marketing, Vol. 20 No. 6, pp. 261-272.

Kaur, G., Sharma, R. and Mahajan, N. (2012), "Exploring customer switching intentions through relationship marketing paradigm”, International Journal of Bank Marketing, Vol. 30 No. 4, pp. 280-302.

Kaura, V., Prasad, C.S.D. and Sharma, S. (2015), "Service quality, service convenience, price and fairness, customer loyalty, and the mediating role of customer satisfaction", International Journal of Bank Marketing, Vol. 33 No. 4, pp. 404-422.

Koo, C., Chung, N. and Kim, H. (2015), "Examining explorative and exploitative uses of smartphones: a user competence perspective examining explorative and exploitative uses of smartphones: a user competence perspective", Information Technology \& People, Vol. 28 No. 1, pp. 133-162.

Liébana-Cabanillas, F., Marinković, V. and Kalinic, Z. (2017), “A SEM-neural network approach for predicting antecedents of m-commerce acceptance”, International Journal of Information Management, Vol. 37 No. 2, 
pp. 14-24.

Liébana-Cabanillas. F., Muñoz-Leiva, F. and Rejón-Guardia, F. (2013), "The determinants of satisfaction with ebanking”, Industrial Management \& Data Systems, Vol. 113 No. 5, pp. 750-767.

Marafon, D., Basso, K., Espartel, L., de Barcellos, M. and Rech, E. (2018), "Perceived risk and intention to use internet banking: the effects of self-confidence and risk acceptance", International Journal of Bank Marketing, Vol. 36 No. 2, pp. 277-289.

McNeish, J. (2015), "Consumer trust and distrust: retaining paper bills in online banking", International Journal of Bank Marketing, Vol. 33 No. 1, pp. 5-22.

Melnyk, V. and Bijmolt, T. (2015), "The effects of introducing and terminating loyalty programs", European Journal of Marketing, Vol. 49 Nos 3/4, pp. 398-419.

Mital, M., Chang, V., Choudhary, P., Papa, A. and Pani, A. (2018), “Adoption of Internet of Things in India: a test of competing models using a structured equation modeling approach”, Technological Forecasting and Social Change, Vol. 136 No. 11, pp. 339-346.

Moon, S.-Y., Philip, G.C. and Moon, S. (2011), "The effects of involvement on e-satisfaction models", Services Marketing Quarterly, Vol. 32 No. 4, pp. 332-342.

Narayanasamy, K., Rasiah, D. and Tan, T.M. (2011), "The adoption and concerns of e-finance in Malaysia", Electronic Commerce Research, Vol. 11 No. 4, pp. 383-400.

Nugroho, Djoko, (2019), Financial Technology Digital Banking, Presented at the Fin tech seminar on 20 October 2019, Paper, Jakarta.

Ranaweera, C. and Sigala, M. (2015), "From service quality to service theory and practice", Journal of Service Theory and Practice, Vol. 25 No. 1, pp. 2-9.

Rawashdeh, A. (2015), "Factors affecting the adoption of internet banking in Jordan: chartered accountants perspective", International Journal of Bank Marketing, Vol. 33 No. 4, pp. 510-529.

Raza,S.A., Umer,A., Qureshi, M.A. and Dahri, A.S. (2020), "Internet banking service quality, e-customer satisfaction and loyalty, The modified e-SERVQUAL model", The TQM Journal, Emerald Publishing Limited, Vol.32 No.66,pp.1443-1446.

Rod, M. and Ashill, N.J. (2010), "Management commitment to service quality and service recovery performance: a study of frontline employees in public and private hospitals", International Journal of Pharmaceutical and Healthcare Marketing, Vol. 4 No. 1, pp. 84-103.

Rod, M., Ashill, N.J., Shao, J. and Carruthers, J. (2009), "An examination of the relationship between service quality dimensions, overall internet banking service quality and customer satisfaction: a New Zealand study", Marketing Intelligence \& Planning, Vol. 27 No. 1, pp. 103-126.

Salimon, M. G., Yusoff, R. Z. B., \& Mohd Mokhtar, S. S. (2017). The mediating role of hedonic motivation on the relations between the adoption of e-banking and its determinants. International Journal of Bank Marketing, 35, 558-582.

Sánchez-Torres, J., Canada, F.-J., Sandoval, A. and Alzate, J.-A. (2018), "E-banking in Colombia: factors favoring its acceptance, online trust and government support", International Journal of Bank Marketing, Vol. 36 No. 1, pp. 170-183.

Siyal,A.W., Donghong, Ding., Umrani, W.Ali., Siyal, S. and Bhand, S. (2019), "Predicting Mobile Banking Acceptance and Loyalty in Chinese Bank Customers", SAGE Open, April-June, pp.1-21.

Tarhini, A., El-Masri, M., Ali, M. and Serrano, A. (2016), "Extending the UTAUT model to understand the customers' acceptance and use of internet banking in Lebanon: a structural equation modeling approach", Information Technology \& People, Vol. 29 No. 4, pp. 830-849.

Yaseen, S. and El Qirem, I. (2018), "Intention to use e-banking services in the Jordanian commercial banks", International Journal of Bank Marketing, Vol. 36 No. 3, pp. 557-571.

Yoon, H.S. and Steege, L.M.B. (2013), "Development of a quantitative model of the impact of customers' personality and perceptions on internet banking use", Computers in Human Behavior, Vol. 29 No. 3, pp. $1133-1141$. 